\title{
Residency Documents for All! Notes to Understand the Movement of Migrants in Barcelona
}

\author{
Amarela VARela
}

\section{Abstract}

This text focuses on a concrete example of the political struggle of migrants which, beginning in the last decade and continuing to the present, occupies Catalan public space in the form of an extremely novel social movement led by migrants from the post-colonial peripheries. These migrants, upon installing themselves in the Spanish state and more specifically in the city of Barcelona, choose to escape the position of victim assigned to them by the "miserablist" representation of immigration to become agents and political subjects. This article is a socio-analytic reconstruction about this social movement which demands the unconditional regularization of all migrants without papers who live in Spain.

\section{Abstract}

Ce texte étudie un exemple particulier de la lutte politique des migrants qui, depuis la dernière décennie jusqu'à l'heure actuelle, occupe l'espace public catalan sous la forme d'un mouvement social extrêmement novateur mené par des migrants issus de la périphérie postcoloniale. En choisissant de s'installer dans l'État espagnol, et plus précisément dans la ville de Barcelone, ces migrants se soustraient au rôle de victime qui leur est assigné par la représentation "misérabiliste» de l'immigration afin de devenir des agents et des acteurs politiques. Le présent article propose une reconstruction socio-analytique autour de ce mouvement social qui exige la régularisation inconditionnelle de tous les sans-papiers vivant en Espagne.

It is absurd to expect women to obey, when inequality is imposed with the force of law. -Fatema Mernissi, El harén en Occidente.

\section{Introduction}

This social movement is made up of organized migrants who live, work, and consume in the territory of the Spanish state like all its other inhabitants. Through weaving webs of understanding with other actors on the local, state, and European level and taking actions including lock-ins, hunger strikes, demonstration, and assemblies, they demand that the Spanish government regularize, without conditions, the situation of all those who are kept in irregular residency situations by immigration policies.

In this paper, I present a synthesis of the sociogenesis of this social movement, the development of its political discourse, and its demands as well as the various strategies used to achieve an outcome where approximately 1 million people obtained their "papers," and with them, certain rights. ${ }^{1}$

The arguments used in this article have been devised and developed in the context of my doctoral research project, on the movement of documented and undocumented immigrants in Barcelona, based on a qualitative approach to the movement, through twenty-three biographical interviews, investigative journalism, and activist or militant research and observation over six years uninterruptedly. ${ }^{2}$

In terms of the theoretical frames, the field of study about social movements of migrants is relatively young and uses the basis of a transnational understanding of social phenomena. The "struggles of migrants," like a new kind of social movement, I propose, can be analyzed from the interpretive frames, or the sociological discourses about collective action and social movements. ${ }^{3}$ We also have academic narratives about the "right to migrate and remain" that are useful to understand these "struggles of migrants. ${ }^{4} \mathrm{~A}$ considerable number of researchers consider political action of the migrants as a new kind of social movement, and they offer analytical approaches of examples of these movements or its demands in different countries. ${ }^{5}$ 


\section{"We Are Not Washing Machines"}

For over a decade Barcelona, the capital of Catalonia, has been the scene of thousands of migrants, with and without "papers," participating as the protagonists of a new social movement ${ }^{6}$ whose demands are that the Spanish government regularize all those who live, work, and consume in its territory.

This movement consists of migrants who are political subjects and who, through their demands and political practices, transport themselves from the position of victim, which the "miserablist" interpretation of immigration has assigned them, to the position of agents. ${ }^{7}$ This allows them to attempt to transform their reality and as part of this, interpolate the European Union in terms of the relations of domination which sustain its liberal democratic regimes as regimes based on the respect of human rights.

As such, these "sin papeles" (undocumented migrants) are activists and migrants. They come from all over the post-colonial peripheries and organize themselves in the form of a social movement demanding "papeles para todos" (residency documents for everyone), freedom of circulation, the right to remain in the place where they have chosen to live regardless of their working life, and equal rights for all those born inside or outside Europe regardless of their ethnic origin, gender, or social class.

All of the above has been said keeping in mind the importance of questioning the work-centred instrumentalism manifest in the management of migrations all over the world, but above all in Europe. ${ }^{8}$ Such a questioning emerges from the experiences of migrants. For this reason, migrants, organized in social movements, use the parallelism of being treated like domestic appliances by saying, "We are not washing machines." As strange as it may sound, this is their way of expressing that migrants are not disposable machines. ${ }^{9}$

Over the past ten years people from the Indian subcontinent, Pakistan, Senegal, Latin America, Morocco, Romania, and elsewhere have organized in diverse collectives with diverse platforms and have demanded the right to a legal existence and with it the "right to have rights," as Hanna Arendt proposes. ${ }^{10}$ This demand is seen as their due and stems from their understanding that they are people who have come from other territories that continue to be intensively plundered by colonial and neo-colonial expansion of the core countries. In short, these political subjects demand of the European democracies the right to decide on their place of residence without having to fulfill any economic function as a form of supposed compensation.

\section{The Protagonists of the Text ... and of the Movement} Echoing the proposal of A. Sayad, ${ }^{11}$ this paper attempts to understand the migrant political struggle from the point of view of its protagonists. The analysis is of their life histories, their stories, including the causes which forced them to migrate, their experience of migration, and how they have become political protagonists in Barcelona.

Furthermore, the paper is presented as a reconstruction which draws on the testimonies, voices, memories, and perspectives which the activists or participants of sin papeles shared during various periods of mobilization. However, as almost always happens with such efforts, I have had to develop from all these histories a single account.

The history of the movement in question is particularly difficult to trace precisely because the majority of activists lack residency documents. Thus, there is continuous movement through this movement. The protagonists are renewed as are the voices which give it continuity. While there is a stable nucleus of activists who maintain over time the basic structures which maintain the movement, in each mobilization the majority of the protagonists reinvent the collective memory of the struggle.

I begin by highlighting that the movement of undocumented migrants in Barcelona is sustained by a collection of organizations that maintain, often precariously, the continuity of their political identity. Their politics is one which is opposed to participating in the politics of integration management of those recently arriving to Catalan territory. That is to say that the sin papeles movement does not form part of the broad network of associations, foundations, and collectives which, through public funding, realize tasks related to social/legal/labour support of migrant collectives. Rather, it is a political movement which acts in coordination with movements opposed to the neo-liberalization of the world system. Thus, it pursues the dismantling of the current border regime.

In order to create links of solidarity, it makes intensive use of new technologies. It is important to take into account that this is a movement which occupies both physical public space and cyberspace. Even though the majority of its activists lack legal existence and deprived of their political rights, they make their acts public. This is all the more striking since according to current Spanish immigration laws, these activists lack the right to gather and demonstrate, the right of association, and the right to unionize and strike.

The sin papeles movement is also a space of tensions, where profound debates are resolved, almost always with urgency, and the most basic necessities are always prioritized; for example, legal residency. It is a movement, its protagonists tell us, which gathers together an indeterminate number of people who have decided to migrate, often because of the desertification of their land, the privatization of previously public economies or the closure of transnational companies. 
Others tell us that they migrate for other reasons: impatience; weariness; or because they are fed up with the institutional corruption (for example, within banks or the public administration). These make it impossible for some to stay. Others are motivated because they have non-normative preferences, in terms of their emotional or political lives. Some examples include the massive embezzlement by European banks in South America, the desertification of the Sahara, the closure of a chain of "maquiladoras" (factories) in Central America, bribing by police agents against small Pakistani businesses, plundering of natural resources by Spanish companies, patriarchal laws which prohibit certain life preferences, etc. In summary, many migrants left their countries of origin because the global economy has no place for them in its account books or in its patriarchal political regimes or even in its environment which is being destroyed through climatic change. Thus, the right which they most strongly defend is, in reality, the fight for the right to stay, not the right to migrate; because migrants organized in Barcelona consider the right to migrate and stay in any territory as fundamental, but also believe that they must fight for the right that nobody is forced to migrate from hunger or political persecution, just as examples.

Upon arriving in Barcelona, the activists relate, they find themselves in the same political space as other Africans, Asians, and Latin Americans, some of whom had come directly from their country of origin while other activists had come to Barcelona having lived in two or three other cities. As such, we may use the term "transmigrants." It is in these shared political spaces that they reinvented their political cultures through the exercise of creating common demands and strategies. They also adapted their collective memory, the history of their previous struggles, in order to identify with that of others.

This was how small farmers from southern Morocco, small business owners from the Indian subcontinent, artists from Eastern Europe, single mothers, and students from the former colonies of the European metropolises came together in assemblies to overcome their migratory pain. As part of this process they reoriented themselves in terms of their everyday life and their understanding of the political, and the role of migrants in Spain

This, then, is a movement which creates social time and space and allows for the integration of migrants without subventions or campaigns. Instead, theirs is an integration which does not simply integrate people as workers, consumers, or taxpayers but as political actors in the city in which they have decided to live. Nevertheless, as recognized in their memories, the most stable activists of this movement, the ones who make the continuity of the movement possible, are mostly leftist activists from different parts of the left spectrum and who update their left political practice upon arriving in Barcelona.

In interviews conducted during the doctoral research, members of the movement of migrants reported and reflected around their experiences of previous political involvement. Among those interviewed, there were those who belonged to trade unions opposed to Franco in the last period of his dictatorship; other interviewees described their militancy in student movements and collectives that fight for the right to self-determination of indigenous peoples in Africa or America. Among the women in the movement there are those who participated, or participate, in collective feminist or women's groups. Also participating in the movement, there are extraparliamentary political party activists, communists, and socialists, members of neighbourhood associations, migrant collectives from Barcelona, that fight in a transnational practice, in the democratization process in their original countries like Pakistan, Morocco, Mexico, Argentina.

Those who participate in mobilizations are numerous and of diverse backgrounds. However, the average profile of an activist in the organization of this social movement is that of North African peasants who have survived the Strait of Gibraltar; Latin Americans who have avoided the police at the airport borders; Moroccan students who have abandoned their universities and are economic refugees and who, as well as being politically active as migrants, form an active part of the Amazigh or Berber diaspora and demand the recognition of their people and the Amazigh language. Another common profile of activists in this movement is that of Catalans and other Europeans who reinvent discourses, political persuasions, and objectives with "workers" from other countries, artists who find in the hybridity of political cultures powerful elements of creation, and, of course, the ubiquitous anthropologists who confirm for the assemblies the transnationalism of migrant practices.

All of these people are the protagonists of a social movement which is unique in terms of its protagonists, demands, and methods, all of which are aimed at achieving the right to have rights and which have their roots in the resistance which the migrants bring with them. These fuse with the resistance that people and groups in Barcelona created to resist the Franco regime and which they recreate to struggle with migrants.

One clear example of this is that today's undocumented migrants undertake lock-ins in churches to demand the granting of residency documents. Only a few decades ago "Spanish" workers, neighbours, and criminalized political activists locked themselves into churches to protest the Franco regime. ${ }^{12}$ 
The activists also tell us that this is a social movement built on the basis of neighbourhood assemblies, one that is in co-operation with religious communities, both Catholic and Muslim, legal and labour accompaniment and reception work with new arrivals. Almost all those involved in this accompaniment emphasize that it cannot be seen only as an assistance service but as a strategy to empower those who have just arrived.

The movement is also built on the planned social encounters between its activists, including dinners, drinks, and dances, sometimes full of nostalgia for their original traditions. One activist points out that these events are not novel because they are intercultural. Instead, she asks, are there any cultures or tastes which are not the result of exchange and mixture?

According to its protagonists it is also a social movement that has been condemned to defeat by all its detractors, including some seen as "intellectual" voices. These voices encourage the movement to consider it "unrealistic" to demand papales para todos (residency documents for all) in a European Union which uses migration as a pretext for new forms of governance. This is a social movement that has been labelled as criminal not only by governmental institutions but also by associations which provide assistance to migrants and the larger trade unions. We're also told that when this criminalization has not been effective those within the institutional spaces have described those in the movement as "manipulated" or "desperate."

The most experienced of the movement respond to the first of these criticisms by arguing that they are just as "idealistic" as women when they demanded the right to vote, just as "absurd" as the native Americans when they demanded their legal recognition as a "people," just as "unrealistic" as homosexuals when they fought for their right to be different, just as "radical" as those who refused to do military service and refused to form part of the Spanish state's war machine.

Movement activists also point out that the neither the undermining nor the criminalization of their struggle is new for many of the migrants in this movement. These actors have already suffered the undermining of their political agency when they struggled in their countries of origin. Moreover, in their respective "back there," each time they disobeyed the imposed order they were told they were "being manipulated" or were merely part of the "desperate hordes." Nevertheless, sometimes they won, because "there is a reason why today's migrations are post-colonial."

We are also told that their movement, like many of today's movements, has reinvented its possibilities by mirroring other movements. The movement in Barcelona closely follows the mobilization of their equals in the United States, such as when its "illegals" decided to give the US a day without immigrants on the 1 May 2006. It also reads with a sense of urgency the texts and proposals of the sans papiers in Sarkozy's France. It has also followed by telephone the lockins of illegalized migrants in Belgium in 2006. And finally, activists attend social forums like the forum in Athens, in which a common plan of action was formulated together with the alter-globalization activists who met at the last European Social Forum.

\section{The History of a Movement Which Fights for the Right to Migrate and to Stay}

The Cuban anthropologist Cecilia Bobes, along with many other theorists of citizenship, ${ }^{13}$ argues that "... citizenship is not an ontological or static condition, rather it exists in relation to political struggles and social movements which demand that the state maintain and even amplify the rights of citizens, ${ }^{14}$ within the meaning of citizenship as a practice that is redefined as the product of social tensions, when migrants require citizenship not to be based on ownership of nationality but rather on residence, the social contract reflecting that citizenship is expanded for the political community as a whole. That is why some authors, including Liliana Suárez, Raquel Macía, and Ángela Morena as pioneers in Spain, propose that the practices of border disobedience by organized migrants "extend" citizenship. ${ }^{15}$

This is the case, I propose, of the migrant struggle led by undocumented migrants organized in Barcelona. Understanding this history is important, not least because it reveals the Europeanization of the relations of domination and forms of social controls operating in Spain today.

The movement arose in the 1990s when the Federation of Immigrant Collectives in Catalonia (FICC) crystallized as a meeting space for a host of then incipient immigrant associations. ${ }^{16}$ Coming from Senegal and Gambia, the Philippines, Morocco, and Latin America, the first organized migrants demanded papeles para todos (residency documents for all).

According to the oldest members of the formal structures of the movement, between 1996 and 2001 the actions of the FICC were supported by hundreds of migrants. Their most important actions were demonstrations in Barcelona, statelevel mobilizations, and legal support and orientation services for those who had just arrived. However, as the geography of migrations in Catalonia became more complex so did the alliances and possible solidarity between immigrant associations.

As the demonstrations and assembles continued, the Papeles para Todos platform was established. This was also the period in which the major trade unions, ecclesiastical structures like Caritas and third-sector organizations 
consolidated their activities in relation to migrant "workers." However, it was in December 2000 that the assembly called Papeles para Todos organized meeting places where migrants and "local" activists came to discuss protest actions against the 2000 Immigration Law. Approved by the two largest political parties, this law, among other things, reduced the political, social, and economic rights of non-EU migrants and amplified the requirements for legal residency in the kingdom of Spain. This law, along with shocking labour accidents in Murcia, generalized the mobilizations across the state. ${ }^{17}$

Through this process, between December 2000 and January 2001, largely undocumented migrants led a relatively spontaneous "flood of lock-ins." ${ }^{18}$ Together they occupied churches and public places in demand of the unconditional regularization of migrants' residency situation, with help from social organizations working on the issue of migration. Through lock-ins, hunger strikes, and symbolic crucifixions, migrant organizations also demanded the repeal of the above-cited Immigration Law. Murcia, Valencia, Zaragoza, Madrid, Almeria, and Barcelona were the cities and societies that "unexpectedly" discovered the presence of the sin papeles demanding an end to the production of illegality by the state. ${ }^{19}$ The movement constantly surprised even the activists as it periodically appeared in public space, above all in Catalonia and Andalusia. These mobilizations (e.g., the waves of lock-ins in 2001, the occupation of Barcelona's Cathedral in 2004, the occupation of the University of Pablo Olavide in Seville in 2002) were possible because they were accompanied by an intense process of grassroots organization and deliberation, which were seemingly invisible to a civil society little concerned with the issue. The practice of church lock-ins once again occupied centre stage in the national press. However, this time those who appeared in the photographs accompanying the news about a political action with a history in the Spanish tate, were Black, Asian, Indian, and Latin American migrants. This was the beginning of a movement which fought for the right to migrate and to stay, to circulate and to remain, for the universal right to have rights.

\section{Logbook of a Journey or Synthesis of Many Efforts}

The social movement of our interest, I propose, has already gone through three constitutive stages. The first and most fruitful of them is that which goes from its genesis in the decade of the 1990s, in which the movement would be known as the "sin papeles movement," and spans temporally up to the wave of lock-ins in 2001. The main demand of this first stage of the movement would be the platform Papeles para Todos.
The movement then underwent a second stage, consolidation of a political identity, in which it transformed from the sin papeles movement to migrantes con o sin papeles (migrants with or without residency documents) movement from 2001 to 2004. The most significant aspect of this stage is the expansion of the normative ideal of the movement, which expanded its set of petitions from "residency documents for everyone" to the demand for "residency documents and rights for everyone."

A third and current stage of the institutive process of this new social movement covers mobilizations from 2006 up to the present when, unlike the previous two stages, Spain is no longer governed by the right-wing party but by the Partido Socialista Español's social democrats. A stage in which the movement's normative ideal, or the main demands for which migrants mobilize, have had to be negotiated at a European level, but above all, have been produced in the context of a global economic crisis in which the role of migrants, as workers and new residents, is threatened by institutional and social racism from a Spain that is entering, little by little, a serious economic recession; therefore the movement's demands and its actions to achieve them have experienced important transformations.

Nevertheless, the period of study of this movement reconstructed in my doctoral research is limited to the first two stages of the process, to constitute the movement up to 2006 .

To explain these periods in chronological terms, let us bear in mind that, as I have already noted, although we can trace the self-organization of the sin papeles back to the $1990 \mathrm{~s},{ }^{20}$ it is not until 2001 that this movement achieved the support of large numbers of people, indeed up to 50,000 people in state-wide demonstrations. Through this, the migrants managed to insert the issue of the state's production of illegality into the institutional and political agenda. In the lock-ins of 2001, specifically in Barcelona, the migrants who went on hunger strikes in nine religious centres came from South Asia, above all Pakistan, but there were also Indian and Bengali citizens. African participants came from Morocco as well as from the central and western parts of the continent. From Eastern Europe there were Romanians, Russians, and Bulgarians. There was also a very small number of Latin Americans. The central demands were the guarantee that there would be no reprisals for the participants of the mobilizations, the end of police abuse of migrants in the city, the regularization of the residency situation of all migrant residents in the Spanish state, and, above all, recognition of direct interlocutors for negotiations between migrants and state authorities.

One of the nine occupied churches housed the "women's lock-ins" which demanded, in addition to the general 
demands, women's autonomy in their receipt of residency; i.e., that a woman's right to remain not be subordinated to the legal concept of family regrouping. Moreover, the participants demanded the recognition of prostitution as a form of work and as such the regularization of sex workers who find themselves in a situation of legal inexistence, even criminalization of themselves.

After twelve days, the first indications of a favourable solution for the participants led to the ending of the hunger strikes but the continuation of the lock-ins. During this period Amazigh migrants from the working-class area of Cornella, who were in the lock-in in the Pilar church, began to come together. Later they would found the organization Cornella Without Borders (CWB), which today represents a social laboratory for new forms of political participation led by migrants.

This is an organization set up by the migrants' movement in Barcelona with the purpose of taking action to combat discrimination in all its forms and which, to this end, strives for revocation of the special legislation outlawing aliens.

As a long-term political ambition CWB thus set itself the abolition of all legislation that established differences between races or that, by stipulating gradations in the acquisition of citizenship, limited people's rights in Spain.

The mid-term aim of the CWB members was to achieve immediate and full legalization of all undocumented migrants residing in Spain; in other words, to defend freedom of movement and the right to remain in the country for all people living and working in Spain.

In the short term, by means of day-to-day strategies, the CWB activists conduct actions designed both to raise awareness and to bring people of differing identities together in order to defuse and dismantle racism, xenophobia, and exclusion. As shown by documents in the CWB archive, this action is "founded on the awareness that recently arrived migrants are not a form of merchandise but persons who, just like the second-generation migrants who have become integrated as Catalonians, are in possession of a wide range of cultural traditions, history and roots that enrich and are enriched by the Catalonian heritage."

By means of various mobilization strategies, which may include demonstrations, sit-ins, or hunger strikes-the strategies employed par excellence by the migrants' movement in Spain - the CWB, in those years of work, has gained recognition among local and regional public authorities as a consultation partner and representative voice, and among the Amazigh (or Berber) community of Moroccans living in Barcelona as an organization able to supply "resources for integration."

Today, among the three hundred members of the association, the majority of CWB members are young people of
Moroccan origin who have become involved through their membership in the Moroccan student movement in Spain or through the struggle for recognition of Amazigh cultural identity.

The organization's priority is to offer free classes in Spanish for recent migrants to the city and legal advice services for those who are undocumented, and at the same time to organize a range of cultural events designed to preserve and enhance the mixed cultural identity of the Berbers living in Catalonia, all throughout the year.

One of the major tasks of the CWB activists is, accordingly, to spread awareness of and give expression to Amazigh cultural identity in a situation of economic exile. To this end, they organize regular activities to promote rights and recognition of the Amazigh, and of their language and culture.

All this work takes place on a daily basis in the form of concrete tasks at the local level. At the national and European level, meanwhile, CWB coordinates its activities with a view to ensuring the "denunciation of and struggle against unjust causes that give rise to immigration, as well as support for development projects run on a basis of involvement of people concerned and taking account of their needs." (CWB archive)

Moreover, CWB activists take part in campaigns to protest against the detention centres and deportation of irregular migrants, and this aspect of their activity is conducted in coordination with other collectives and anti-racist organizations in Spain. In terms of any impact on the majority trade unions, CWB's capacity for dialogue or influence on trade union policies or action strategies is virtually nil.

However, CWB does work closely with the Confederación General del Trabajo de Catalunya (CGT-Catalunya, General Confederation of Labour of Catalonia) in all matters concerning the public denunciation of and legal claims relating to labour law infringements or those generally referred to as "workplace accidents." This is a particularly frequent and problematic issue among the migrant workers who, insofar as they are deprived of legal recognition, also lack the possibility of recourse to the law or to health and safety provision in their workplace

Even so, there is an absence of political trust between $\mathrm{CWB}$ and the major trade unions such as Comisiones Obreras (CCOO) or the Unión General de Trabajadores (UGT, General Workers' Union) provided that, from the perspective of the CWB activists, the major trade unions are among the agents involved in negotiating extraordinary regularization procedures that are decreed by the Spanish government every so often and which lay down specific conditions for obtaining papers. This practice is in blatant contradiction with the stance of "papers for all men and women living and working in Spain" adopted by CWB. 
Going back to the narrative of the movement's history, in 2001, the same moment students took to the streets and the classrooms to support the demands of the migrants. In the first days of February 2001, there were lock-ins in the faculties in the Polytechnic University of Barcelona and the Pompeu Fabra University.

As a result of the above, as well as from political pressure from the Catalan Left, NGOs, and public figures, forty-eight days after the beginning of the lock-ins, the government of the Partido Popular (Popular Party) was forced to recognize the participants of the struggle as "legal subjects." Through humanitarian procedures deemed to be "exceptional," the participants obtained residency documents and work visas. As such, if the participants of the lock-ins failed to achieve the repeal of the Immigration Law, they succeeded in putting in motion a process of the regularization of their residency situation. That is to say, as a social movement, they were able to strategically recognize the correlation of forces and achieve real solutions to the conflict.

Afterwards, the protagonists of the " 2001 lock-ins," as this citizenship movement became known, formed a state-wide platform which was, however, quickly dissolved. The reason for the rapid dissolution, as so often happens with large mobilizations which are subjected to extreme pressures, was that the lock-ins left the movement deeply fractured.

Why? As I've argued above, the ideological matrix of the activists is not homogeneous, and their political practices are much less so. However, another key reason is what remains one of the main paradoxes of this political project: upon obtaining residency permits and working visas the participants found themselves obliged to maintain a stable working life, with the consequences that this means in terms of time for political participation. Either they worked and paid taxes or lost their residency permits. This fracturing of the movement represented more of an opportunity than a problem, for some of the most constant activists, as it disseminated the demands and political identity of the sin papeles into different spaces. However, this fracturing did have negative consequences.

In July of the same year, more than 200 migrants from sub-Saharan Africa and Morocco camped in Barcelona's main square, the Plaza Catalunya, demanding the regularization of their residency situation.

However, thirty days later, and after months of sleeping outdoors, these activists were evicted by an order from the municipal government. Attacked by the police, they moved to three different squares to continue their camp until finally, on the 17 August, 2001, after a charge by the police, 115 migrants were interned in the Verneda Immigrant Detention Centre. In the following days many of them were deported to their respective countries. The media gave these incidents little coverage.

The regional government justified the police action, claiming that the demands were "unsustainable." Today we know, owing to the declaration of a high-ranking civil servant, that the repressive response was really a part of a protocol for action in cases of migrant mobilization. The lock-ins of 2001 took the authorities by surprise; afterwards all migrant mobilizations were followed by similar repressive reactions.

In recovery from such a repressive strike and with the movement split into almost a dozen social organizations with little coordination, in April 2003 the migrants, with support from the platform Papeles para Todos, realized another camp whose aim was to simultaneously agitate for the regularization of their residency situation and protest the war in Iraq.

Months later, the same platform supported more than 600 migrants from Africa, Latin America, and Eastern Europe who occupied the old military barracks of Sant Andreu in Barcelona and turned it into their refuge. This was an unprecedented step as the occupants of the barracks managed to turn a spontaneous occupation into a physical space form which they could coordinate themselves and demand both the right to housing and the right to legal existence. However, after several months, confronted by the passivity of a large part of the network of associations in Catalonia, the migrants were evicted. The migrants were expelled from the area and the barracks were demolished. One of the leading figures was jailed in the Verneda Immigrant Detention Centre for forty days. ${ }^{21}$

It is in this mobilization cycle that the first stage of the institutive process of the migrants' movement in Barcelona culminates.

The second stage of this process begins, I propose, months later, as part of an attempt to maintain a presence on the streets of Barcelona, when a demonstration of 8,000 people on the 31 January, 2004, took to the streets demanding the "Unconditional Regularization" of all migrants resident in Europe. With this European Day a new slogan emerged, which is more a normative ideal than a real political praxis: if the border regime is European, the resistance must also be European.

In February of the same year the Assembly for Unconditional Regularization (AUR) was set up. This platform reunited and renovated the alliances between migrant communities, organizations, and people working in the networks of associations. The platform's goal, according to its press releases, is "to struggle for full access to civil, economic, social and political rights and duties for immigrants in the Spanish state." 
From its formation up until the occupation of Barcelona's Cathedral on 5 June, 2004, the platform held assemblies, meetings, events, and demonstrations with other collectives and groupings in order to find common ground within the struggles.

Three years after the 2001 lock-ins and following months of organization, 1,500 migrants occupied the Cathedral to pressure the central government into taking their key demands seriously: unconditional regularization and the repeal of the Immigration Law. However only eight hours later, the police entered the Cathedral and violently evicted the migrants. Although no one has been able to confirm this fact, it has been reported that eleven migrants were detained and deported the following day.

The testimonies of all the protagonists of the movement insist that the eviction took place with the consent of the recognized NGOs and associations of or for migrants, as well as the trade unions and the Catalan political parties. The socialists' José Luís Rodríguez Zapatero had just become president of the Spanish government and, as was accepted years later, many of the organizations who backed the repressive police action held a generalized belief that his government would flexibilize the immigration regime.

Despite this the migrants kept taking to the streets, fasting outside the Cathedral with the support of grassroots Christian groups, holding assemblies, and searching for alliances. In December 2004 several Latin Americans imprisoned in the Verneda Immigrant Detention Centre began a hunger strike that lasted only a few days. The sin papeles platforms supported the action with a camp outside the Verneda. The government quickly proceeded to deport all the participants.

At the same time, the pressure for regularization was mounting. According to various sources, at the time there were 2 million sin papeles in Spanish territory. For this reason, in the first days of 2005 the migrants of the AUR once again began a lock-in. For three consecutive days they demanded unconditional regularization, an annulment of detentions and deportation orders for undocumented migrants, the closure of the Immigrant Detention Centres, the repeal of the Immigration Law, but above all, the establishment of talks with the new socialist government.

In this context of assemblies, demonstrations, petitions, and hunger strikes, 2 April 2005 arrived and with it the European Day for the freedom of movement and the right to remain. On 2 April in Barcelona, as in more than twenty European cities, almost 5,000 people demonstrated to demand the unconditional regularization of all migrants living in the Spanish state, to defend the right to the freedom of circulation, and to demand the right of people to remain in the place where they choose to live. At the end of the demonstration, as planned, more then 500 immigrants began a chain of lock-ins in Barcelona and its outskirts, specifically, L'Hosptalet, Cornellà, Sant Vicenç del Horts, Santa Coloma de Gramenet, Sant Boi, and Terrassa. As part of the same action the sin papeles also began hunger strikes.

This was to be the last large-scale mobilization of the movement in this second period of the constitutive process of the movement. In it the migrants carried out lock-ins in ten different places such as trade union offices, universities, churches, squats, and community centres. Churches were included because, at the time, the Catholic Church closed its doors to the migrants and, as recognized months later by a senior in the hierarchy, this was done partly as a result of "the recommendations" of the regional and state authorities. This can be explained, I propose, because a good part of the associations "for migration" which have by now consolidated themselves as "ethnic grouping in Spain" were involved in lobbying which, along with religious associations and important unions, were striving for a migratory reform that the social democrat government had promised its voters during the electoral campaign for presidency the previous year.

There was no migratory reform but an extraordinary regularization process, or an amnesty for migrants who had arrived in Spain previous to 2004; this was the sixth process of this kind. According to the organized migrants, this process was badly managed as it left 1 million of the 2 million sin papeles in the same situation of legal non-existence and vulnerability.

In this new chain of lock-ins the migrants demanded the flexibilization of the requirements for obtaining residency permits. In order to obtain residency it was necessary to have a permanent job (in an economy in which nine out of ten contracts are temporary), to be registered on the city register (even after the latest legislation on immigration had granted access to the city register to the national police leading many migrants to not register), and to be able to demonstrate a clean criminal record (yet another difficult requirement for the citizens of countries in conflict situations, as are many of the countries of origin of African migrants).

For this reason, hundreds of migrants and "nationals" participated in the lock-ins for fifty-three days, and 20 of them undertook hunger strikes. Nevertheless, from the beginning of the lock-ins, the government only considered flexibilizing the requirement to be registered on the city register. They introduced a type of procedure which created an arbitrary situation in which a lot was left to the discretion of the city governments.

In these lock-ins the support of Spanish civil society was scarce. According to the veteran members of Cornella Without Borders, three key elements produced this lack of 
support: the change to a socialist government, the media representation of migration as a problem, and the fear of people of Arabic or Muslim origin which, from the perspectives of some of the activists, was intensified after the terrorist attacks of 11 March in Madrid. Once more, the main groupings which sustained the mobilizations were Pakistanis, Amazigh from Morocco, Senegalese, and Gambians. Moreover, Latin American migrants were notable for their absence in this process, although they are the majority of migrants in the Spanish state.

According to the AUR, more than 800 people participated in the process. Among them were migrants who had been in Barcelona for much more than six months but were unable to demonstrate it according to the requirements, migrants who had come from other parts of the Spanish state, especially Andalusia, and even migrants who had moved from other parts of Europe.

The 2005 lock-ins were followed by an assembly entitled Residency and Rights for All in Ribas, Madrid. This was an important date as part of which the sin papeles movement of Barcelona participated in setting up the state-wide coordinator for the Rights of Migrants. ${ }^{22}$ This platform participated in the coordination of the simultaneous celebration in forty Spanish, European, African, and US cities of the International Day for the rights of migrants on the 7 October 2006.

Today, the central demand which sustains the sin papeles is significantly more elaborate than "residency documents for all" and it reaches beyond the nation-state to the transnational level:

We demand a different politics: Respect for natural wealth and its legitimate owners. Drop the debt and end support for the corrupt regimes of the world. End the externalisation of borders. End police brutality and the detention and deportation of immigrants. Close the Immigrant Detention Centres, the present one at the Verneda and the future one in Zone Franca. Unconditional regularization of the residency situation of migrants. Respect and equality of labour, social and political rights for migrants and for all those who live in the territory of the Spanish State. A respect which makes absolutely necessary the abolition of the Immigration Law. ${ }^{23}$

That is the reason why I propose that, in the third stage of the migrants' movement in Barcelona, not analyzed in the doctoral research sustaining this article, the normative ideal of the movement has been broadened to more complex bids than simply the regularity of the legal statute, such as the disappearing of old special laws establishing differences between individuals born in Spanish territory in those who arrived as migrants in it.
It is important to note the scenarios that can be foreseen in what, in this article, is called a third stage of the institutive process of the migrants' movement in Barcelona, provided that even if its analysis and understanding are not a part of the effort of the doctoral thesis sustaining the text, it is interesting to try and discern them even as a prognosis of a social process of this size.

Certainly, after the impasse in 2005, there has been a conformation of a new association in this case driven by the Pakistani, Hindu, and Bengali communities settled in Barcelona, which calls itself Papeles y Derechos Para Todas $y$ Todos (residence documents and rights for everyone). Other historical activists from platform Papeles para Todos and a good part of individual members of the Assembly for Unconditional Regularization (AUR) have adhered to this new organization.

On the other hand, the Amazighs associated in Cornella Without Borders still take part in the AUR even though there has been an important change in direction in terms of what the association's activists prioritize. In this stage the members of the CWB, cornelloneros, as they are known within the movement, are found in the construction of organizational and meeting spaces for Amazighs living in Barcelona, apart from the Spanish classes and demonstrations and actions demanding the overthrowing of old laws that keep on discriminating against them as foreign.

Because of personal decisions, but above all as a reflection of the transnational Amazigh movement, CWB members have begun to establish a dialogue with the Catalan administration and with Amazigh ethnic organizations and associations, in order to build a common path. And there, the AUR and other migrant movement organizations may go along with the cornelloneros in public acts, but not in building with them that derivation of their militancy.

In this third stage also, the antiracist Catalan movement and other solidarity groups with the migrants have built their own discourse, more complex compared to the previous stage, about the borders regime of the European Union; and its role in the migrants' movement is an active and challenging one vis-à-vis the central government.

In addition, an explosion of the demands by the migrant collectives is produced in this stage and new initiatives emerge, which do not relate to the migrant movement organizations as described so far, whether because of mutual ignorance or political differences.

It is then the subject of future research projects, or other researches, to accompany the emerging progress of migrants as a social movement, and to do so in a socio-analytical way, from the participant-action research point of view.

In this new stage, the social transformations being brought about by the global economic crisis both in Spain 
and at a regional or even global level will, without a doubt, intervene in a nodal way. At the time of closing the writing of this article, four million unemployed are being reported in this country and the sectors where the crisis is deeper are precisely those in which more "migrant labour hand" is used, such as construction, care services, hostelling, and agriculture, all of them sectors with no possibility to move towards the peripheral regions outside Europe, and provided the global scenario, sectors that will very likely start to be occupied again by Spanish workers with a citizenship statute that is not subject to their working role.

Therefore, from my sociological perspective, the challenge for the migrants' movement is to deepen the discourse on inalienable human rights, rather than putting the economic and social role played by migrants in the Spanish economy before them.

Thus, the diagnosis of the sociopolitical trajectory of migrants who decided to organize themselves as a movement is reflected on this timeline of the conflict; the prognosis of what is to come for the movement corresponds to a different research work, among other reasons, because it will respond to a context clearly differentiated from that which was lived in the protest cycles that we have tried to analyze so far.

\section{By Way of Conclusion}

In this article I have narrated that, as a social phenomenon, viewed from the perspective of the sociology of dissidences and the sociology of migrations, the migrants' movement in Barcelona reveals a novel collective political identity which is not to expire with the obtaining of the "papers," but this demand is merely the starting point for a much larger trajectory including the universalization of every citizen's rights.

By creating a biography of this movement I discovered that, viewed as a whole, the migrants' movement transformed the initial political identity of being "undocumented" in Spain towards an identity sustained in time, as it is reflected in the three stages of the movement, which is sustained from its genesis and has consolidated due to stable organization structures that expand their set of demands, according to the situation and political moment, and that recognize themselves as the migrants' movement in Barcelona.

In a nutshell, all through this work it has been shown that the migrants' movement in Barcelona is living an institutive process, sustained by the social actors who sympathize or actively militate in it, and who came together in a collective political identity conformed by two central elements: the pluri-ethnic composition of its members and, particularly, the hybridization of their individual political cultures.
This collective identity is instituted in the Catalan social movement's imaginary through establishing stable coordination structures, such as the AUR which gathers several collective actors, among which the organizations Papeles $y$ Derechos para Todos and Cornella Without Borders stand out.

A social movement of a new kind has been built through decision-making mechanisms in deliberative meetings and with a very high degree of complexity, and by the way community and affective links among migrants operate to summon the movement and make it work.

This is a settled political identity which rapidly renews its composition, almost as fast as the "migratory flows to Spain," because the main reasons for collective action of those organized in the migrants' movement are to make visible, to denounce, and to transform or even suppress the internal and external borders system determining the everyday experience of those who live with a migrant status, with or without "papers," in Barcelona, Spain, and the southern part of the European Union, because for the main characters it is within this borders system where racism emerges in its institutional and social dimensions, and this borders system is precisely what their movement opposes.

To illustrate this institutive process of the political identity of the migrants' movement in Barcelona and the transformation of this identity over time, some of the preformative practices and the resources through which this movement is achieving its institution, as a product of political tactics negotiated interculturally, have been described in this article.

The social usefulness of this text attempts to contribute so that the normative ideal of this movement is considered by social and institutional actors as a believable and viable alternative to disarticulate the social and institutional racism with which the consequences, not of the migratory phenomenon itself but of the human migrations administration policy, are approached and dealt with.

This reflects two central thoughts: to consider migrants organized in a social movement as a fundamental speaker and counterpart to rethink citizenship as a legal statute and as an expression of social participative relationships and to consider their organization strategies as an exercise to expand citizenship in itself.

\section{Notes}

1. I arrived at this approximation by comparing data from the National Statistics Institute from 1 January 2009, which states that approximately, 5.5 millions of people on the city register are "non-nationals." On the other hand the statistical bulletin (31 March 2009) of the Secretary for State, Immigration and Migration puts the figure for 
non-nationals resident in Spain at 4.5 millions of people. CITE (Area Migraciones of the Spanish Trade Union "Comisiones Obreras") recognized in 2005 the existence of $1,200,000$ undocumented migrants.

2. My doctoral thesis consists of five chapters that explain the methodological model of research, the main reasons for collective action of those migrant workers movement organized, a chronological detailing of the stages and cycles of mobilization of organized migrants; it presents a summary genesis about this social movement, and the evolutionary development of political discourse and demands, in addition to the different strategies that these activists carried out, according to the mobilization and political context, to ensure that persons who lack legal recognition as subjects obtain their "papers" and with them some rights. Finally, it reflects about some clues that the political practices of migrants contribute to the debate on citizenship rights as a device, because it aims to understand this social movement as an extension exercise of citizenship that extends this notion. See Janik Amarela Varela Huerta, "Porque la ciudadanía se consigue ejerciéndola. Una aproximación sociológica al proceso instituyente del movimeinto de migrantes en Barcelona" (The Citizenship Is Gained by Exercising, a sociological approach to instituting process of the movement of migrants in Barcelona), (doctoral dissertation, Universitat Autonoma de Barcelona, 2010), online: http://www.migracat.cat/document/3c14dc26b41f772.pdf.

3. See Doug McAdam, "Marcos interpretativos y tácticas utilizadas por los movimientos: dramaturgia estratégica en el Movimiento Americano Pro-Derechos Civiles," in AA.VV. Movimientos sociales. Perspectivas comparadas (Madrid: Istmo, 1999); Antonio Melucci. "Asumir un compromiso: identidad y movilizaciones en los movimientos sociales," in Marisa Revilla (ed.) Movimientos sociales, acción e identidad, (Zona Abierta No. 69. Madrid, Siglo XII, 1994): 153180; Xavier Godás, Política del disenso. Sociología de los movimientos sociales, (Barcelona, Icaria, 2007)

4. See Etienne Balibar, "What We Owe to the Sans Papiers," in Social Insecurity, ed. Guenther and Heesters (Toronto: Anansi, 2000); Seyla Benhabib, The Rights of Others: Aliens, Residents and Citizens. (Cambridge: Cambridge University Press, 2006); Sandro Mezzadra, Derecho de fuga: migraciones, ciudadanía y globalización. (Madrid: Traficantes de Sueños, 2005).

5. See, as examples: Peter Nyers, "Abject Cosmopolitanism: The Politics of Protection in the Anti-deportation Movement," Third World Quarterly 24, no. 6 (1993): 1069-1093; Natasha Pearce, "How Can Migrants Organize Themselves?" (paper, in Future Conditions of Works: Trade UnionsMigrants- Women, Hamburg, 25-26 November 2000); Helen Schwenken, "RESPECT for All: The Political SelfOrganization of Female Migrant Domestic Workers in the European Union," Refuge: Canada's Periodical on Refugees 21 (2003): 45-52; Teresa Hayter, Open Borders: The Cases against Immigration Controls (London: Pluto Press, 2000);
Cynthia Wright, "Moments of Emergence: Organizing by and with Undocumented and Non-citizen People in Canada after September 11," Refuge: Canada's Periodical on Refugees 21 (2003): 5-15; In Spain there are two key authors, Liliana Suárez and Peio Airbe; for the French case see Abdallah, Cissé, and Diop; all of these authors are mentioned below.

6. The field of study on the "struggles migrants" is relatively young and uses the basis of a transnational understanding of social phenomena. The migrant struggles, like a new kind of social movement, I propose, may be analyzed from the interpretive frame, or the sociological discourses about collective action and social movements; see McAdam; Melucci; Godás.

7. The "miserablist" interpretation of immigration in Spain, as a concept, has been developed by Enrique Santamaría. It proposes that the hegemonic academic discourse for understanding migration in Spain assigns for the migrants the category of criminals for transgressing the European external borders without legal documents, or these discourses choose to represent migrants as victims of the legal regime without any kind of autonomy. In any case, in both perspectives the migrant subject is interpreted as criminal or victim and not as a protagonist of his own migration project. See Enrique Santamaría, ed., Retos epistemológicos de las migraciones transnacionales (Madrid: Anthropos, 2008); also Enrique Santamaría, "Sobre la utilidad de los inmigrantes," in V Congreso de Inmigración en España (Valencia: Universidad de Valencia, 2006), online: http:// www.adeit.uv.es/inmigracion2007/index.php (accessed June 2010).

8. As is known, to gain access to residency permits in Spain or in Europe it is a condition sin qua non to be working, as such safeguarding the relations of production. The other possibility is to obtain permits through family regrouping with a worker and in this way to reinforce the relations of reproduction, caring, and an effective return on labour.

9. There is an interesting reflection of this discourse in the mobilization of migrants with and without documents elsewhere. Since 2006, as part of a campaign called Uni(e) $s$ contre une immigration jetable, one group has demanded that the French government abandon its current instrumentalism as a criterion for the granting of rights to "non-national" or non-European subjects. For more information on the content of the campaign see: http://www .contreimmigrationjetable.org/. (accessed June 2010)

10. Hannah Arendt, Los orígenes del totalitarismo (Madrid: Taurus Ediciones, 1998).

11. Abdelmalek Sayad, L'immigration, ou les paradoxes de l'alterité (Brussels: De Boeck-Wesmael, 2001)

12. It is important to establish the continuity of this mobilization strategy. Certain popularized texts have considered, almost as an axiom, the lock-ins led by migrants in Spain, above all in 2001, as mirroring the church lock-ins of the Sans Papiers in France. In my own interviews there are 
more identifications with the lock-ins during the dictatorship in the Kingdom of Spain than with the Sans Papiers. It is important to highlight this so as to make clear that both are points of reference in the collective memory of the migrant struggle. For the Sans Papiers movement, see: Mogniss Abdallah, The Sans Papiers Movement: A Climax in the History of French Immigration, http://www.noborder .org/without/france.html (accessed June 2010); Madjiguène Cissé, Palabra de "sin papeles" (Donosti: Gakoa, Tercera prensa, 2000); Abdabacar Diop, Dans la peau d'un sanspapers (Paris : Editions du Seuil, 1997).

13. See Javier De Lucas, "La ciudadanía para los inmigrantes: una condición de la Europa democrática y multicultural," Eikasia Revista de Filosofía, No. 4. (2006): 1-19; also Liliana Suárez, "Ciudadanía y migración: ¿un oximorón?" Puntos de Vista, No. 4 (Ayuntamiento de Madrid, Madrid, 2005): 29-47; Liliana Suárez, Rebordering the Mediterranean: Boundaries and Citizenship in Southern Europe (New York and Oxford: Berghahn Books, 2004).

14. Cecilia Bobes, "Ciudadanía," in Léxico de la política, ed. Baca, Bokser, and Castañeda (Mexico City: FLACSO, 2000), 50-53.

15. See Liliana Suárez, Raquel Macía, and Ángela Moreno, eds., Las luchas de los sin papeles y la extensión de la ciudadanía: Perspectivas críticas (Madrid: Traficantes de Sueños, 2007).

16. I have information on other mobilizations, such as the lock-ins by Moroccans and Algerians in Valencia in 1990 demanding regularization. We also have information on organizations like the Association of Moroccan Immigrants in Spain. However, here we are dealing with the testimonies of the activists who are still active today.

17. See Barbara Laubenthal, "La emergencia de las protestas de inmigrantes sin papeles en España: el caso de la región de Murcia," in La condición inmigrante: exploración e investigaciones desde la Región de Murcia, ed. Pedreño, Hernández (Murcia: Universidad de Murcia, 2005), 159-174

18. Suárez, Macía, and Moreno, eds.

19. Peio Airbe, "La irrupción de los 'sin papeles," Mugak 14 (2001): 14-16.

20. This process is also paralleled by the updating of the legislation on immigration enacted by the Spanish government when it entered the European Union.

21. La Jornada sin Fronteras; 30 November 2003 and 22 February 2004, http://www.jornada.unam.mx/2003/11/30/ mas-cara.html (accessed June 2010).

22. For information on the activities of REDI, see http:// rediestatal.wordpress.com/category/redi-estatal/ (accessed June 2010).

23. Manifesto of the AUR, June 2006, http://barcelona .indymedia.org/newswire/display/265981/index.php (accessed June 2010).

Amarela Varela, doctorate in sociology from the Autonomous University of Barcelona, is a lecturer at the Autonomous University of Mexico City and also a journalist. An earlier version of this text was presented at the conference Alien Confinement in Europe: Field Perspectives, during September 2007, École des hautes études en sciences socials, Paris. 